\title{
MULTIFUNCTIONAL LANDSCAPES FOR URBAN FLOOD CONTROL IN DEVELOPING COUNTRIES
}

\author{
M.G. MIGUEZ, F.C.B. MASCARENHAS \& L.P.C. MAGALHÃES \\ Computational Hydraulic Laboratory, Federal University of Rio de Janeiro, Brazil.
}

\begin{abstract}
The urbanisation process changes the natural landscape, generally aggravating flood problems. In developing countries, urbanisation is not always accomplished by the implementation of the adequate infrastructure required. Lack of planning frequently worsens this situation. Focus on urban flood problems has been changing in the last few decades. The traditional approach that basically worked on the drainage net, by canalising and rectifying water courses, is being complemented or substituted by different concepts. One new approach tries to achieve a systemic solution for the basin, with distributed interventions aiming to recover pre-urbanisation flow patterns and combining water quality and quantity control aspects. These modern concepts deal with techniques known as 'best management practices'. In densely urbanised environments, however, it is not always easy to find suitable areas available for construction of detention reservoirs or extensive infiltration measures, for instance. In such a situation, an interesting option may be the use of multifunctional landscapes, in which urban solutions gain additional hydraulic functions, combining urban planning and hydraulic engineering aspects to revitalise urban environments in a sustainable manner. The use of existing parks and squares, remodelled to aggregate permanent or temporary ponds, can be an interesting option for flood control. In developing countries, however, as in the city of Rio de Janeiro, Brazil, water quality problems due to untreated sewage disposal are generally more crucial than those associated with watershed washoff. This article presents a case study related to the urban basin of the Joana River, which is one of the major tributaries of the drainage net of the centre-north zone of Rio de Janeiro city, which contains traditional town districts. The article presents a comparison, in terms of flood levels, between scenarios that consider the present situation and a combination of traditional and alternative flood control measures. This assessment was carried out using a mathematical cell model and the results presented show the potential benefits that can be achieved through the use of multifunctional landscapes with flood control features. This type of solution points to the combining of architecture, urbanism and engineering to help in solving flood control problems in urban environments, especially those that are a reality in developing countries. Finally, the City Hall intervention, which was developed based on the ideas proposed in this article, is presented.

Keywords: integrated flood control projects, mathematical modelling, multifunctional landscapes, urban floods.
\end{abstract}

\section{INTRODUCTION}

The present urban model adopted by most of the cities appeared in Europe in the second half of the 19th century. This model focused on the concept of a 'functional city' with large urbanised spaces (squares, avenues, gardens, wide streets) allowing better movement of people and goods as well as conforming districts with better integration between people and urban and natural environments. However, urbanisation is a man-made action that generates great environmental impacts. Some of them, especially those related to land-use changes, have direct consequences on the drainage system, and may be felt as flood aggravation, decrease of dry season discharges, water quality deterioration and, therefore, fluvial and estuarine ecosystem degradation. Understanding the ways in which the urbanisation process acts on floods is very important for adequate urban planning. Combining structural and non-structural measures, integrated with urban master plans, and the use of urban landscape structures with hydraulic functions allow a composition that is able to deal with urban flood problems in a sustainable manner. Regarding the problem, it must be stressed that the solution is closely related to the understanding that the basin works as a system, where single actions may only change problems in space and time but often cannot provide the desired flood control level. 


\section{A BRIEF REVIEW OF THE HISTORICAL GROWTH OF CITIES}

The Industrial Revolution marks the beginning of a deep change in society. The decreasing death rates combined with increasing production pictured a general growth trend. From this moment, there was a rupture in the secular equilibrium in which each generation tended to occupy the place of the preceding one. In this way, cities began to grow quickly, encompassing a natural population increase and migration fluxes. At the same time, liberal economists maintained that public intervention should be limited in all branches of social life, including urban questions. The consequences were critical to the functioning of cities. In the first half of the 19th century, the problems of industrial cities appeared to be too numerous to be completely eliminated. Original city centres did not support the ever growing housing and traffic needs adequately. City centres started to become vacant and poorer. Peripheral areas began to be occupied by districts of different characteristics in a compact urban pattern [1].

The post-liberal city appeared as an alternative to the industrial city. This time, freedom given to the private enterprise was limited by the intervention of the public manager, establishing limits for regulations and acting in public works for the welfare of the people. In this context, public administration managed to put the city to work in a minimal adequate way. Commerce and circulation of goods were privileged to the detriment of other productive activities. As a consequence, modern urbanism searched for an alternative city model in which 'artists' and 'technicians' started to work together to try to reach a better equilibrium of the built environment. Modern architects criticised the contrast between public interest and private property and indicated as an alternative the re-conquering of the public control over all city spaces [1].

In developing countries, however, due to their late industrialisation, the process of population growth occurred faster and was concentrated in the second half of the 20th century. In this context, the situation of a built landscape adequately designed, in a city guided by urban plans, is related only to a part of the population. The other part is not in a condition to be assisted by services from the formal city and organises by itself in irregular conditions. Poverty and lack of infrastructure lead to urban chaos. The formation of an irregular city put aside from a regular one forces reconsideration of the modern architectural development. Architecture and engineering are placed at the crossroads created and they need to find solutions to recover the irregular city, providing the needed infrastructure

(a)

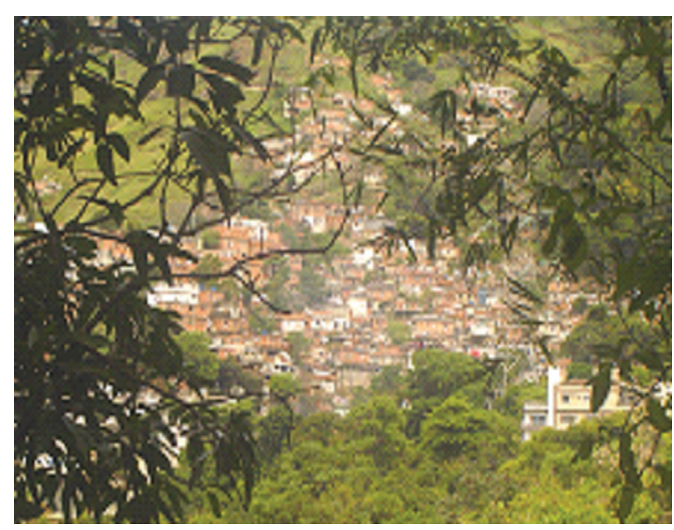

(b)

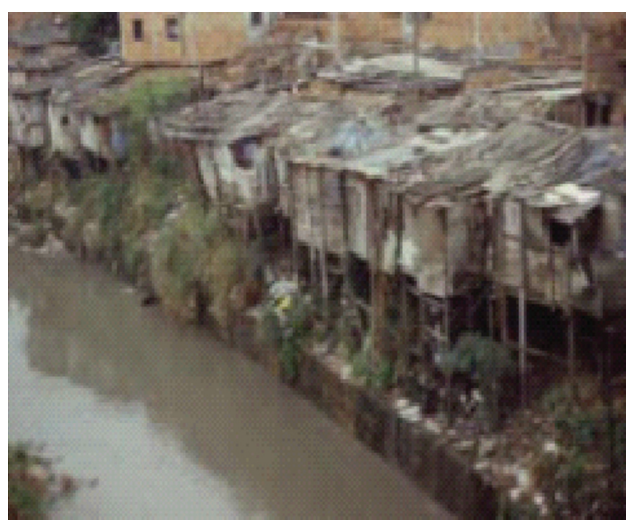

Figure 1: Irregular city growth: (a) hill occupation with vegetal cover removal; and (b) riverbank constructions along an urban river (Rio de Janeiro, Brazil). 
and developing urban plans that correspond to the real needs of local communities and stakeholders. Figure 1 shows two examples of the growth of an irregular city in Rio de Janeiro, Brazil.

\section{URBANISATION PROCESS AND URBAN FLOODS}

Natural floods are caused by high run-off rates generated due to intense rainfalls. The urbanisation of a watershed generally tends to aggravate floods as it promotes the removal of original vegetation coverage, increases imperviousness, canalises river reaches and promotes the occupation of flood plains (Fig. 2). Therefore, greater water volumes flow more quickly over the basin and finally accumulate in low-lying areas, which are often densely populated. When urbanisation is not adequately planned, the consequences of this process may become critical and cause life and material losses as well as social and economic problems, besides great annoyance for the population. Frequent floods reduce the quality of living of communities, reducing property values and discouraging investment in the affected region. In some cases, this process leads to a progressive impoverishment of the area, as some local households lose all their belongings during each flood and it takes a long time for them to recover from these losses.

In developing countries, it is generally observed that a disordered city growth, without adequate control of land-use changes and without adhering to an urban master plan. The city as a centre of attraction, favouring the migration of a low-income population in search of better living conditions, suffers from this non-programmed population flux and these new and poorer inhabitants occupy critical zones which, in many cases, constitute areas protected by the law. In this way, the necessary infrastructure that would be required is not provided, thereby forming slum areas of a huge nonregular city. The result, in terms of the urban drainage question, presents a general frame of cities without adequate drainage and sanitation systems, with high population density and a great social pressure.

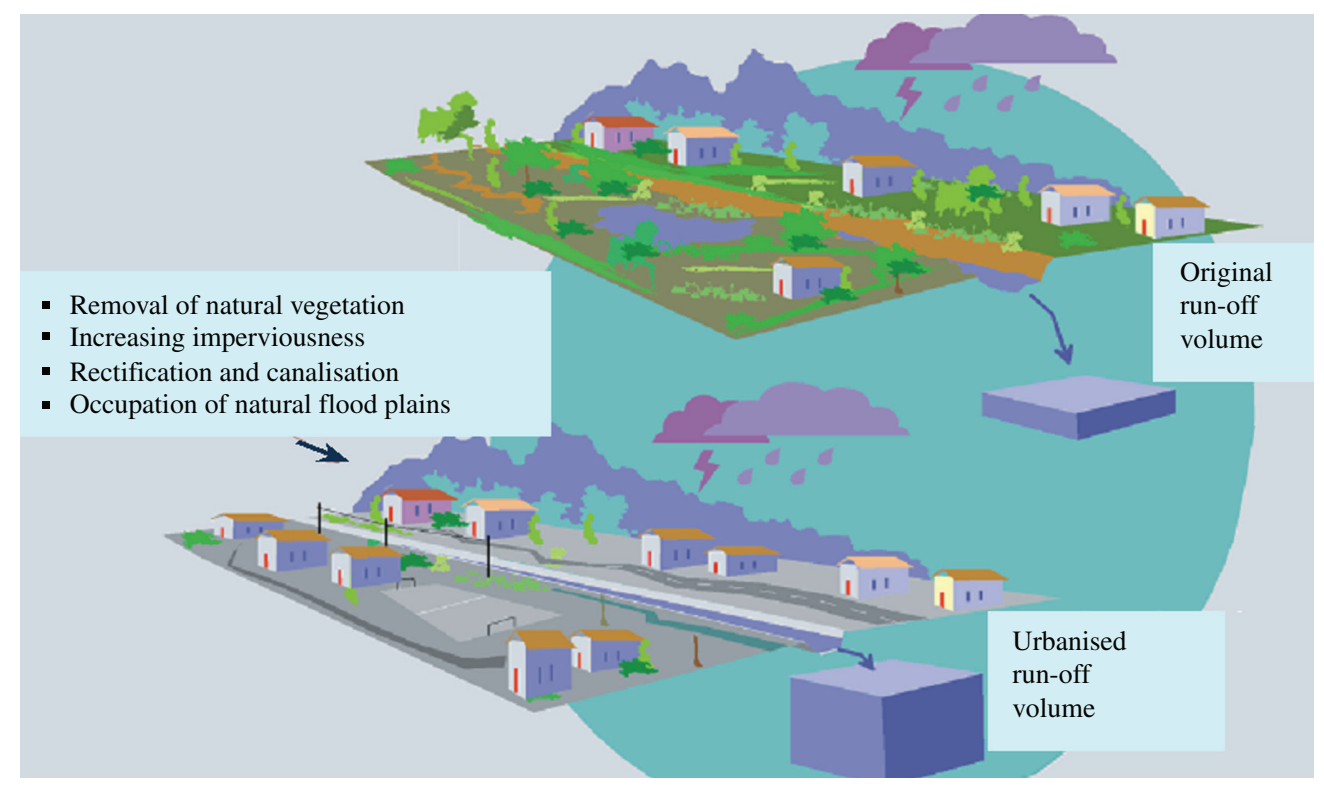

Figure 2: Effect of the urbanisation process on natural floods. 
In some cases, the urbanisation process progresses until a level at which very high imperviousness and demographic density rates are achieved, with a generalised occupation of the basin, including areas that are naturally subjected to floods. In such cases, the flooding consequences are critical. At this point, the urbanised region can be considered as an ultra-urban environment. In such a situation, the range of structural measures available for flood control becomes more limited, as the lack of free areas and the high cost of properties restrain the intervention possibilities. In this context, traditional solutions may not only transfer the problem to downstream reaches but they are also difficult to implement. Therefore, distributed flow control can be an important alternative, once it acts at the source of the problem. These kind of structural measures are often cheaper than traditional enlargement of drainage channels [2].

\section{FLOOD CONTROL MEASURES AND URBANISTIC SOLUTIONS}

In the recent past, traditional urban drainage practices focused on the problem of drainage elements conveyance, trying to modify the channel geometry to the resulting flow, which involved major canalisation work and high costs. This technique acts directly on concentrated flows, differentiating it from the technique of distributed interventions. More recent trends involve the use of the so-called best management practices (BMP) and the concept of low impact development. BMP is defined as a set of planned actions implemented in a watershed with the goal of promoting the attenuation of the impacts of urbanisation, taking into account water quantity concerns and water quality aspects [3]. Coffman et al. [4] have recommended the use of low-hydrologic impact projects, which consider the use of measures that aim to re-establish the storage and infiltration conditions that existed before the urbanisation of the catchment. Distributed control of surface flow generation should be considered not only for on-site areas but also for public spaces, such as streets, sidewalks and squares. In some cases, the flow re-distribution may be achieved through detention or retention structures varying from large reservoirs, locally damping discharges from large watershed portions, to smaller reservoirs distributed over the urban landscape. Therefore, the urban flood problem is presently being considered from a new point of view in scientific and technical discussions. It is assumed to be more important to treat the problem at its source, in a systemic way, with distributed actions over the urban landscape to decrease and delay flood peaks and also allow groundwater recharge, thereby recovering flow conditions that are similar to conditions of the natural flow. In this way, seeping pavements, on-site detention reservoirs, detention ponds, infiltration trenches, reforestation, green areas preservation, sidewalk gardens and greenways, among others, can be good solutions to achieve the proposed goals, and can also integrate the urban environment harmonically as some of them can be designed as recreation areas during dry seasons, thus taking on the characteristics of multifunctional landscapes.

Many cities have been working to minimise the impacts of concrete surfaces. The city of Saarbrücken, in Germany, for instance, has developed a programme of subsidies for projects that allow water conservation and decrease in surface flow. Some detached actions are related to projects for harvesting and use of rainfall water, projects for substituting impervious pavements with vegetation or seeping pavements and projects for green roofs construction [5].

Schilling [6] has studied the use of water tanks in Germany in a residential area of 2.69 ha where $29 \%$ of this area represents building roofs. Using 140 water tanks each with a capacity of $0.5 \mathrm{~m}^{3}$, he obtained reductions of $10-20 \%$ in the peak discharges for different return periods. For frequent floods (recurrence less than 1 year), the reduction reached 80\%. O'Loughlin et al. [7] analysed the use of on-site detention varying according to the type of construction. This study was carried out in Sydney, Australia, where the Municipal Council has implemented the use of on-site detention, and incorporated it into the construction and government land-use guidelines. 

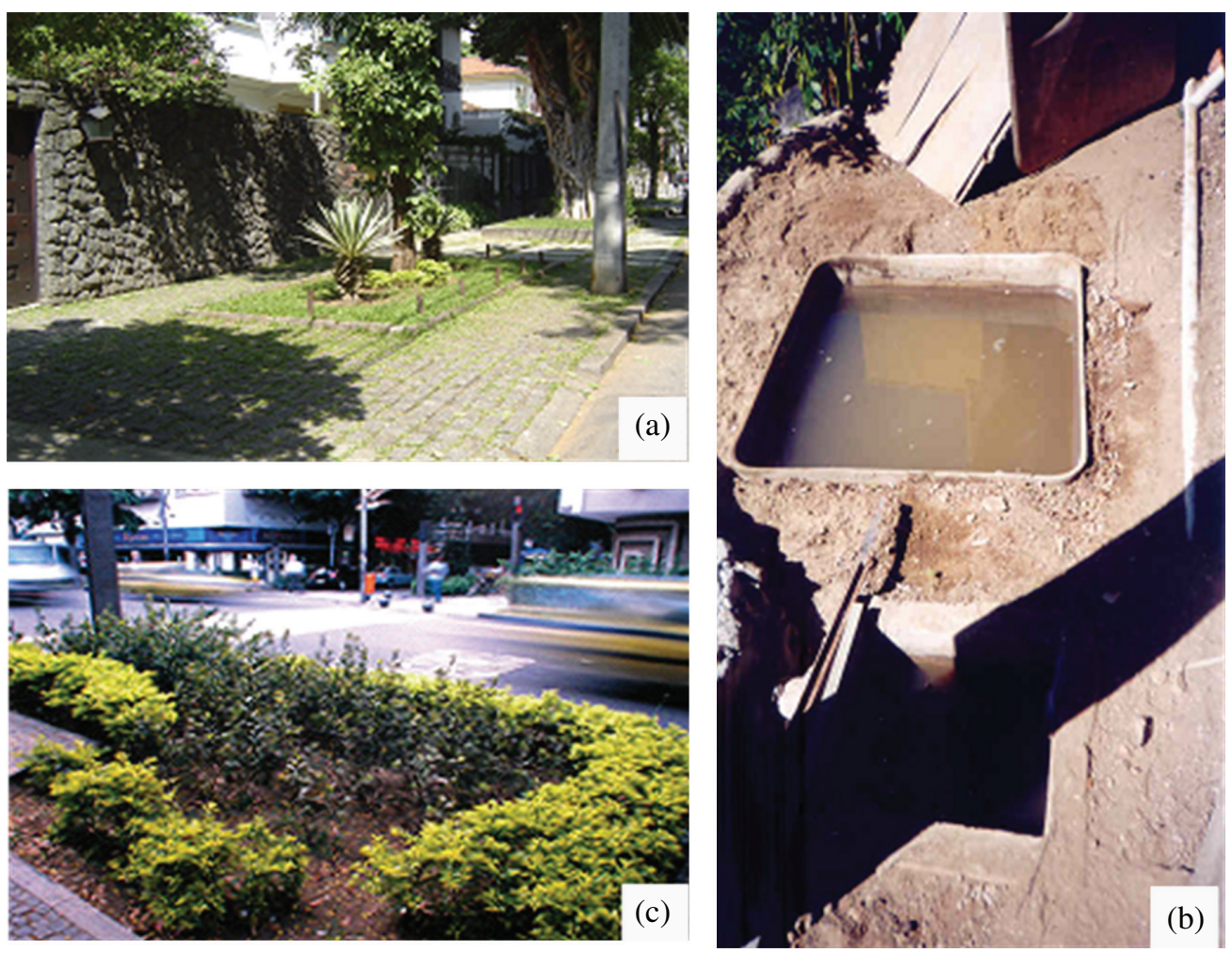

Figure 3: (a) Seeping pavement; (b) on-site detention tank; (c) rain garden.

Hall and Porterfield [8] have stressed the importance of run-off control in their search to find solutions to recover the harmonic design of communities, by arranging their growth in a sustainable manner while preserving the landscape characteristics. These authors state that detention or retention basins used for flood control can be also used as amenities, when designed with imagination, that help to create healthy and functional environments, favouring the conservation of a diversity of vegetable and animal species as well as adding aesthetical aspects that help to increase land value. Integration of drainage solutions with revitalisation programmes for urban areas can be an important option for the flood problem solution, either by projecting distributed actions over the urbanised basin, not only focusing on the drainage net, or by the optimisation of public resources, when financing works with multiple purposes. Figure 3 shows different examples of flood control measures integrated with urban solutions.

\section{MATHEMATICAL MODELLING AS AN AID TO EVALUATE INTEGRATED PROJECTS}

Urban watersheds tend to have a high potential to produce large inundated zones. When leaving the drainage system, water flow paths may be different from that of the drainage net, according to the urban patterns. Sidewalks along channels may become weirs for the rivers; spilled water flows through the streets, which work like channels, and the storage of water in the streets, buildings, squares or parks make these areas work like reservoirs, although in an undesirable way. This extreme situation gets worse when micro-drainage does not work as expected, which is often the case, especially in 
developing countries, due to obsolescence, lack of maintenance or obstructions generated by the presence of litter and flood debris carried by the flow. In fact, when micro-drainage does not work as expected, flooding in urban areas can begin even without the spilling of macro-drainage.

In this context, for a diagnosis of urban flood problems and to propose integrated urban flood control projects, it was found that the use of a distributed mathematical model, which can represent the systemic hydrologic and hydraulic characteristics of the basin, can be very useful. The construction of MODCEL, an urban flow cell model [9-11] based on the concept of flow cells [12], provided a valuable tool for urban floods solution design and research. The representation of the urban surface by cells, acting as homogeneous compartments, results in a flow net that is able to integrate the entire basin. Each cell performs rainfall run-off transformation and the flow net interacts through cell links, considering various hydraulic laws. Together, these features make up a suitable approach for a mathematical model of urban floods. Different types of cells and links provide versatility to the model.

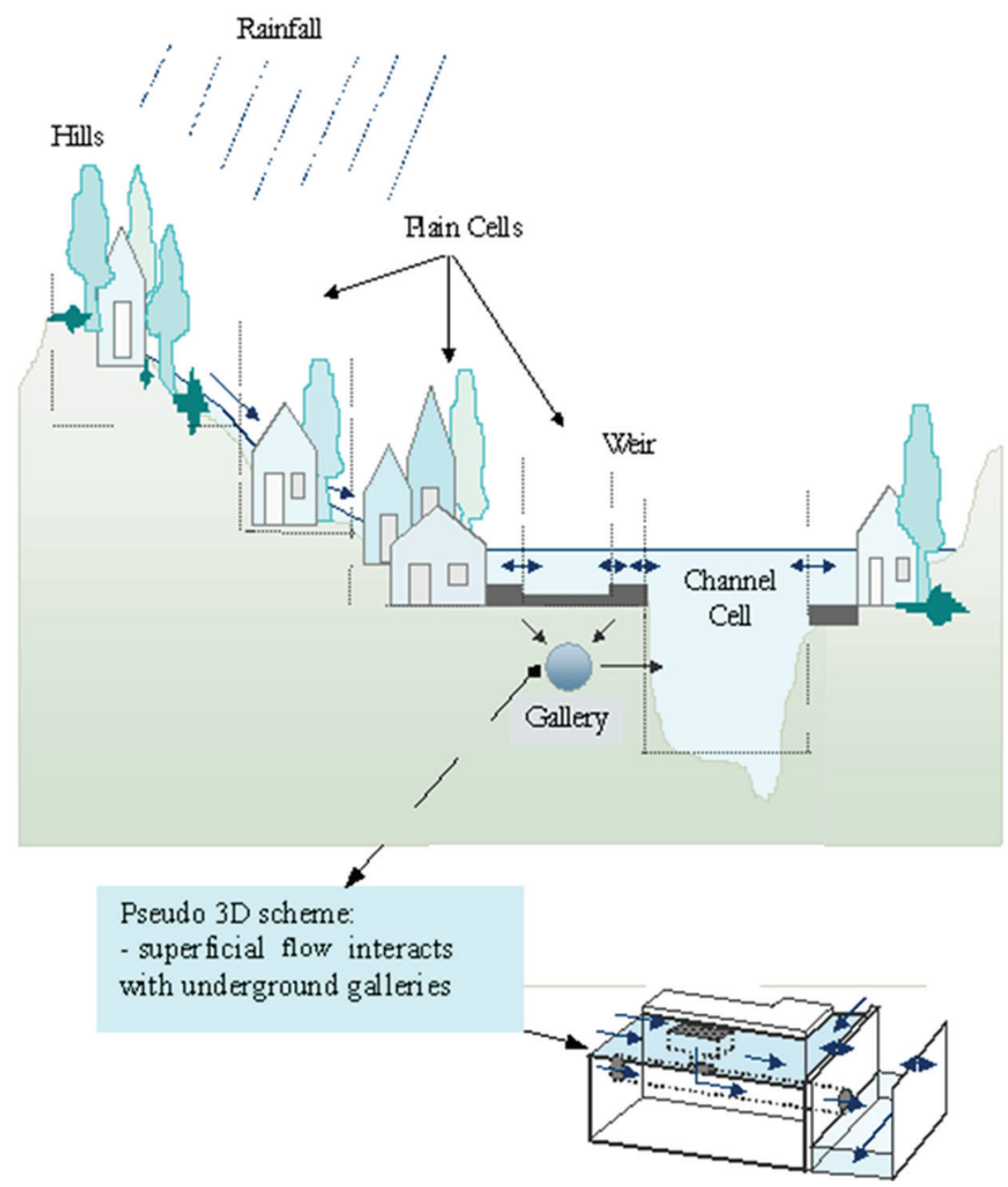

Figure 4: Schematic representation of a region divided into cells, showing different interactions and flow patterns. 


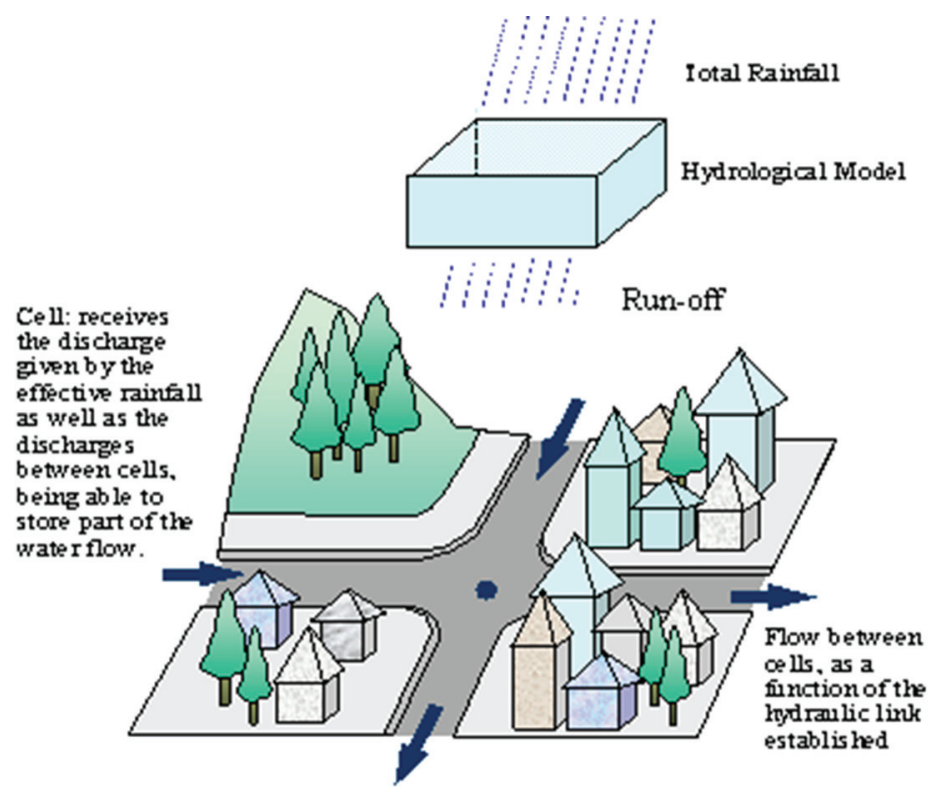

Figure 5: Sketch of flow cell behaviour.

Figure 4 shows a catchment profile, where it is possible to see a cell division and the interaction between cells, while Fig. 5 shows schematically the hydrological process in a cell.

\section{CASE STUDY: CITY OF RIO DE JANEIRO, BRAZIL}

The city of Rio de Janeiro, in the southeast of Brazil, presents a highly urbanised environment, with many irregular occupations in slope areas, and it suffers regularly from urban flood problems. In this town, the City Hall has been developing, since 1993, a revitalising programme of the urban space, acting on public squares, re-defining streets alignment, creating new parking areas, re-forming sidewalks and also re-formulating the drainage net at places of action. This programme is known as 'Rio-Cidade'. However, this municipal programme action focuses mainly on the use of traditional measures, concentrating efforts on galleries and channel enlargements. This treatment given to the drainage system sometimes transfers the flooding problem to areas located downstream. This study undertook a critical evaluation of the Rio-Cidade programme for the districts of Vila Isabel, Andarai and Grajau, in the Joana River catchment.

With the aid of the mathematical cell model discussed previously, a set of alternative project scenarios were constructed to compare the effectiveness of the projects implemented under the RioCidade programme with alternative measures by considering a 10-year recurrence design rainfall with a critical duration for the basin.

The enlargement of the gallery containing the Joana River, carried out by the City Hall in the middle reach of the studied basin, has the potential to minimise problems in that region; however, a simulation performed using the mathematical model shows the transfer of the flooding to a downstream critical area for city traffic, where originally the river did not spill out of the watercourse (Fig. 6). This is an example of the consequence of not planning integrated actions for the whole basin.

The proposed alternative interventions were done in the context of multifunctional landscapes, avoiding actions on the existing drainage net and controlling the generated flows in a distributed way. 


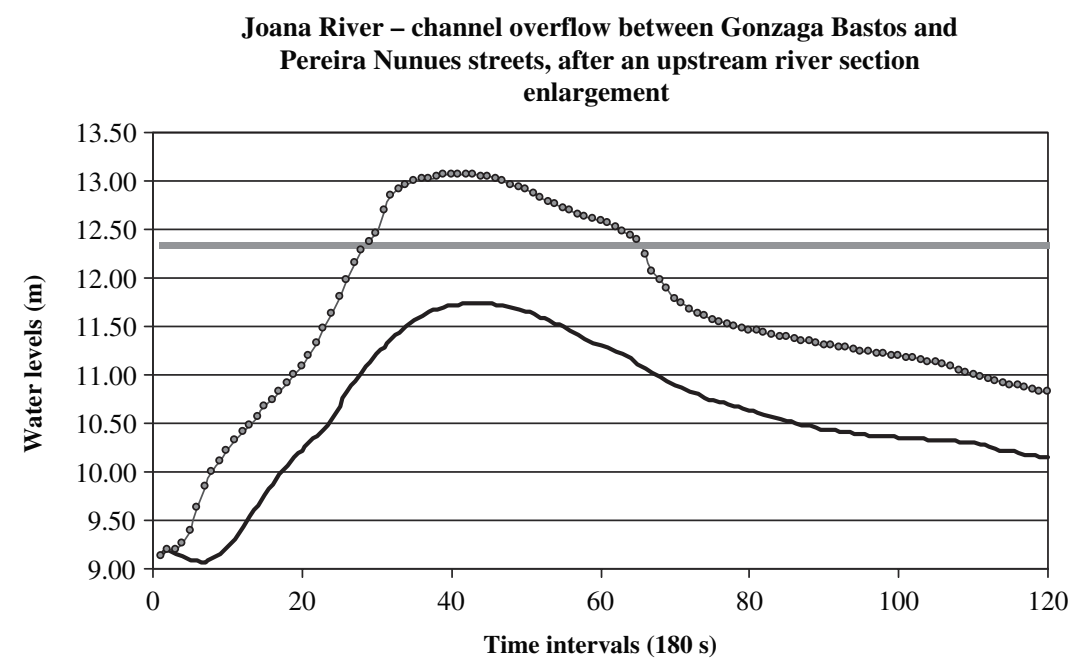

-Original Situation —Channel Enlargement $\longleftarrow$ River Bank/Street level

Figure 6: Flooding aggravation in a downstream area after a traditional canalisation intervention, for a 10 -year recurrence time rainfall.

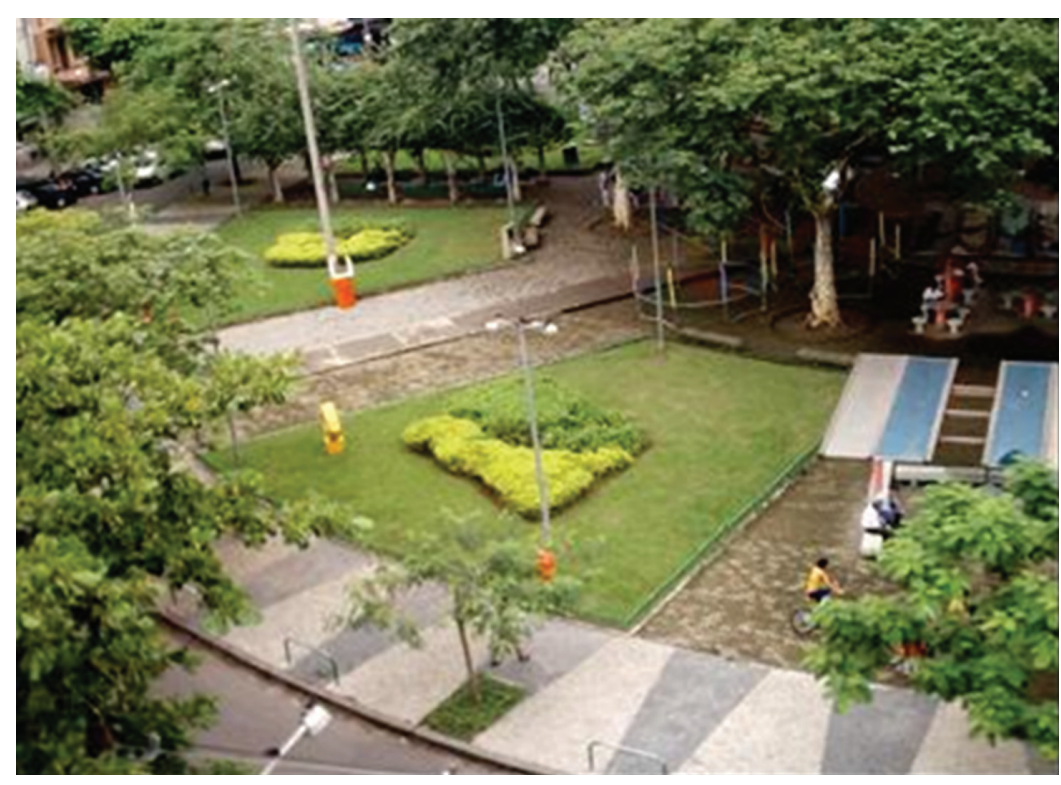

Figure 7: Partial view of Edmundo Rego Square.

Among these actions, there is the possibility of re-urbanisation of squares to make these places work as temporary detention ponds, the use of seeping pavements on sidewalks and the proposal of rain gardens. All these actions would take into account the restrictions of free areas, so the urban revitalisation considered in Rio-Cidade, working on parks, squares, streets, parking lots and other public areas, could include hydraulic functions in the design of new urban landscapes. 


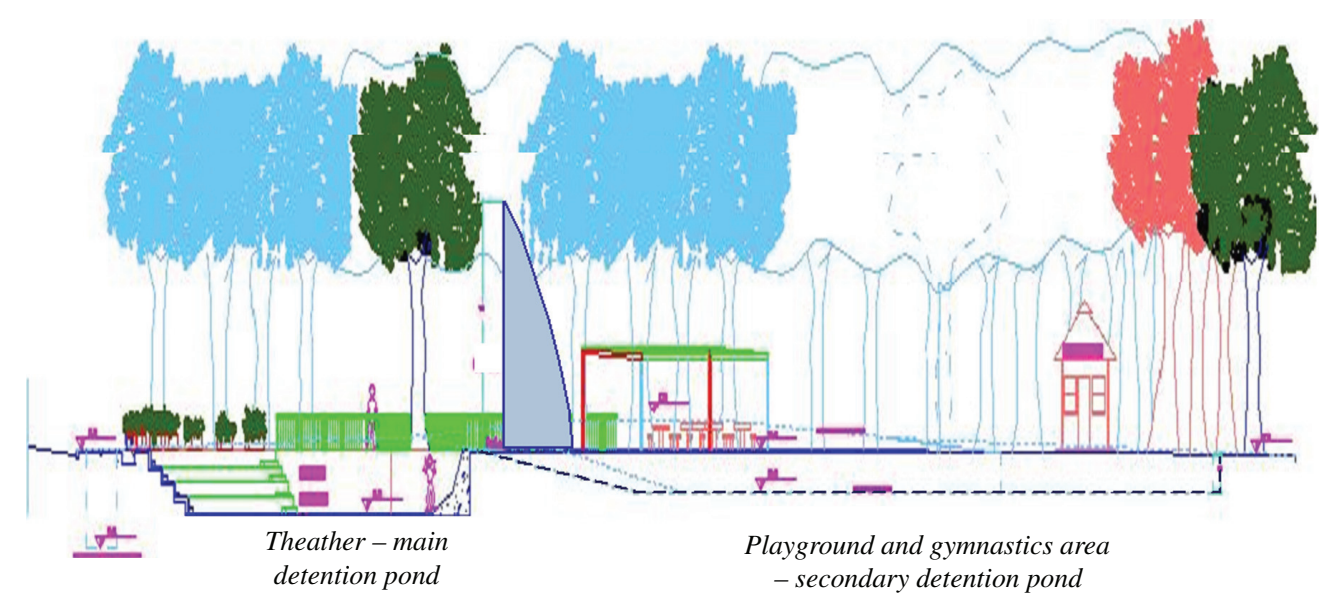

Figure 8: Profile of Edmundo Rego Square in the alternative project, with areas at different levels acting as temporary reservoirs.

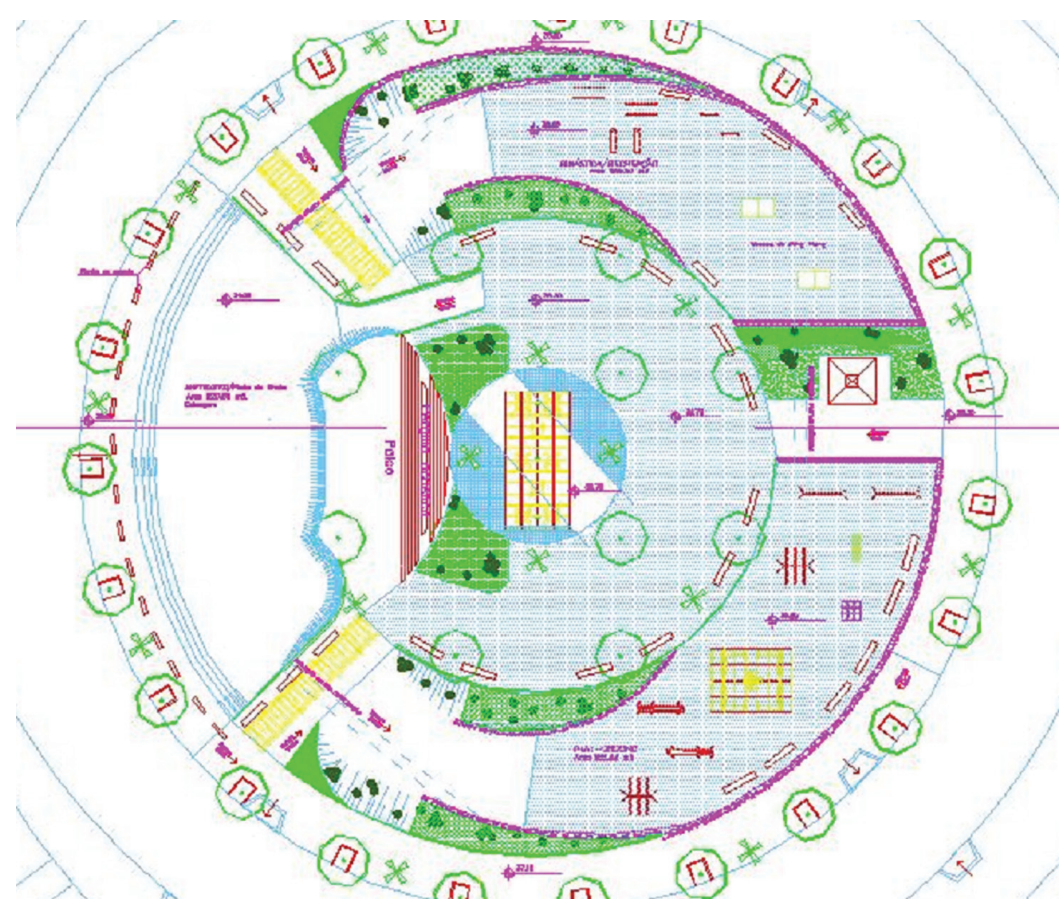

Figure 9: Plain chart of the architectural project proposed as an alternative scenario for Edmundo Rego Square.

As an illustration of the above discussion, Fig. 7 shows a partial view of Edmundo Rego Square as it is today, after the Rio-Cidade intervention. Figure 8 shows a profile view of the alternative project proposed for Edmundo Rego Square, in the Grajau district, with areas at different levels. These different levels would allow selective flooding according to the recurrence of the rainfall, until 


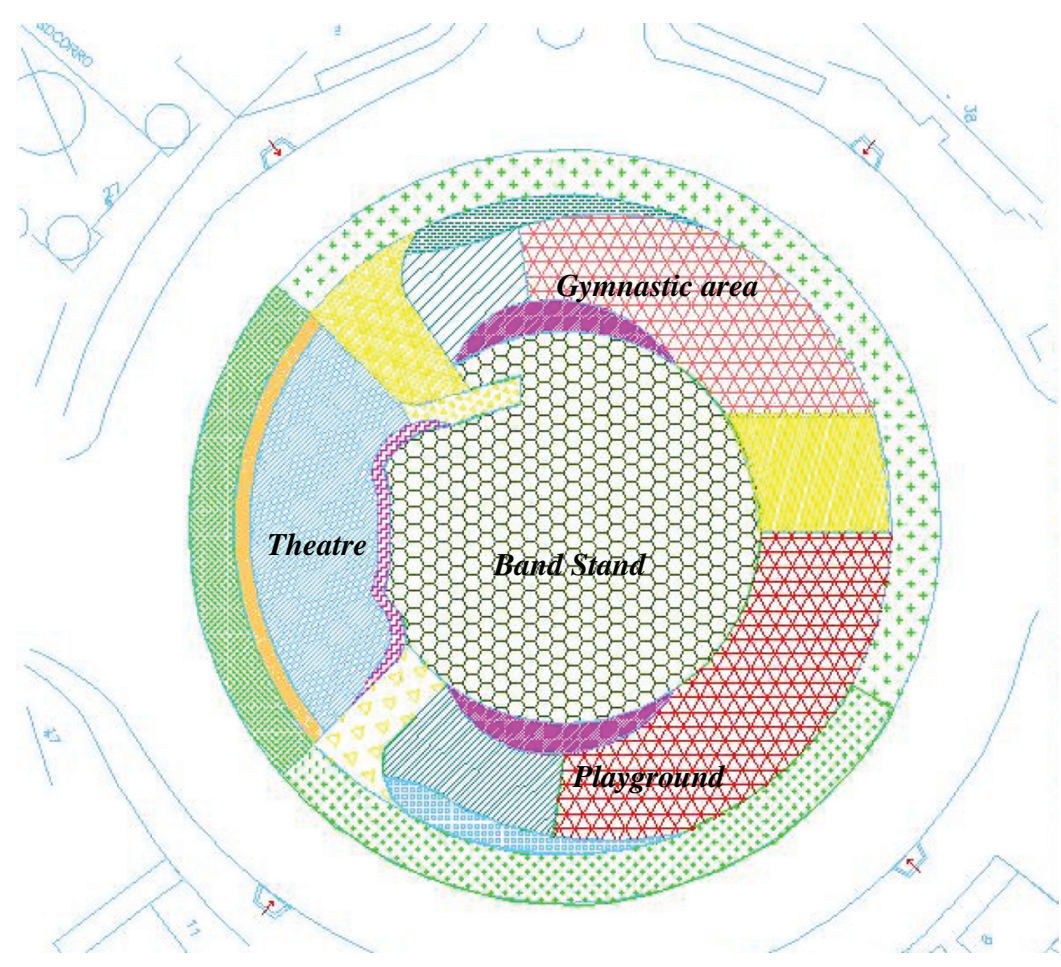

Figure 10: Schematic delimitation of areas at Edmundo Rego Square in the alternative project.

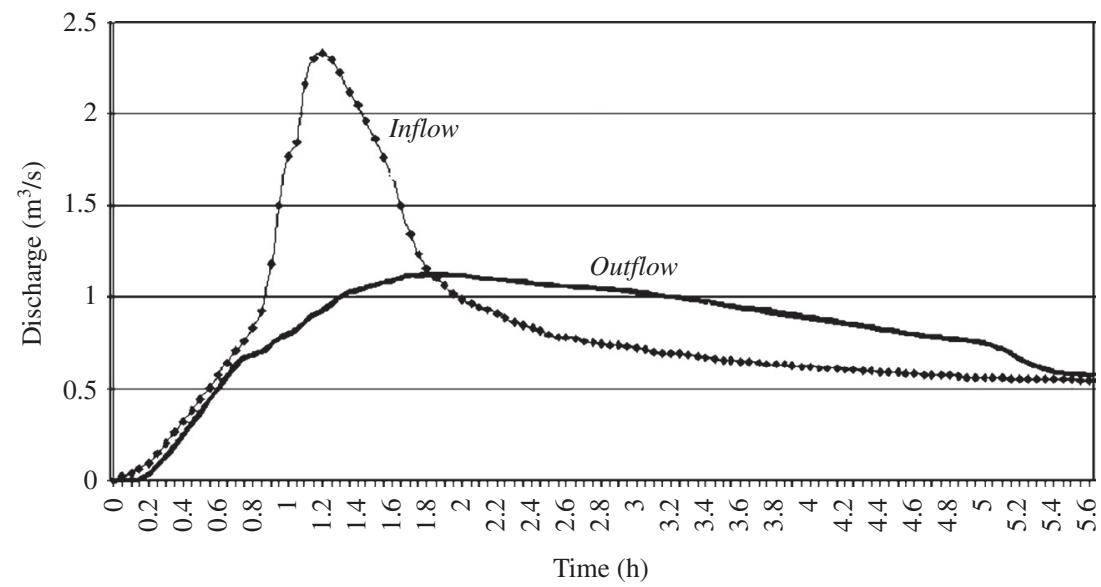

Figure 11: Damping result in the square compared to the inflow hydrograph.

it reaches its limit at the design rainfall. In this way, frequent floods would not interrupt the usage of the square. More importantly, floods would require a clean-up maintenance plan to be put into practice immediately after the rainfall event. Figure 9 shows a plain chart of the proposed architectural project, and Fig. 10 shows the delimitation of areas inside the square. Figure 11 shows the hydrograph 


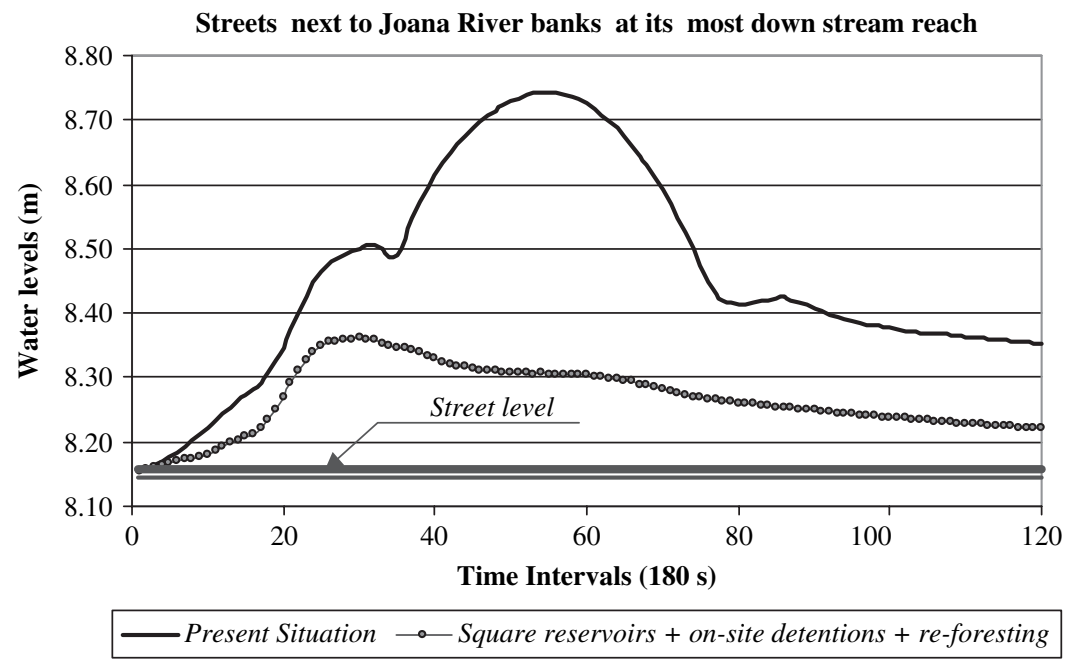

Figure 12: Computed result of flooding levels over streets, near the basin outlet, through the effect of a set of square detention reservoirs, onsite detention tanks and slopes reforestation.

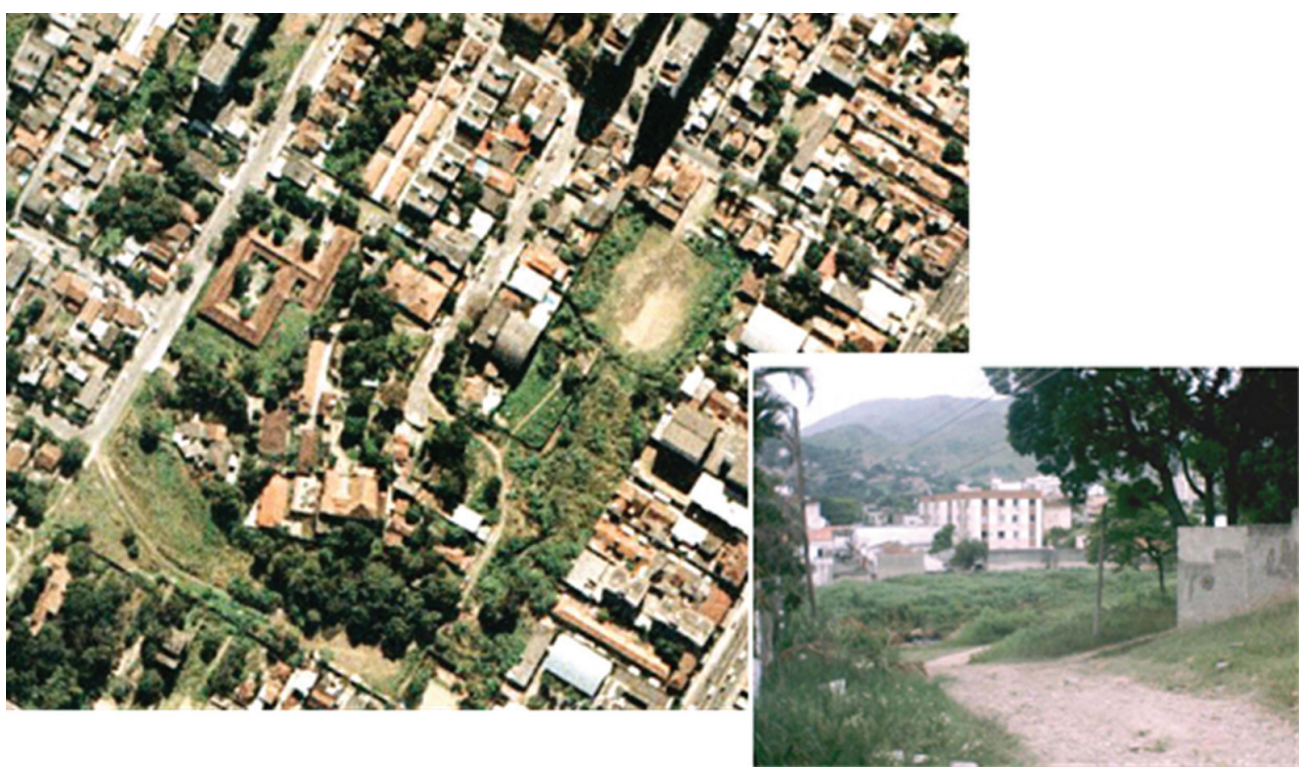

Figure 13: Aerial view of the region of Pinto Teles Park and a detailed view of the site (inset).

with the damping result for the Edmundo Rego Square detention pond. Figure 12 shows the results obtained for a simulation scenario at a downstream reach of the basin, where inundation is a serious problem. This scenario considered the extensive application of the concept of transforming public squares into functional landscapes with the aim of flow detention, leading to the implementation of detention reservoirs in 11 squares of the basin, and also considered the widespread adoption of the concept of on-site reservoirs in the middle reach of the basin as well as reforestation actions to 


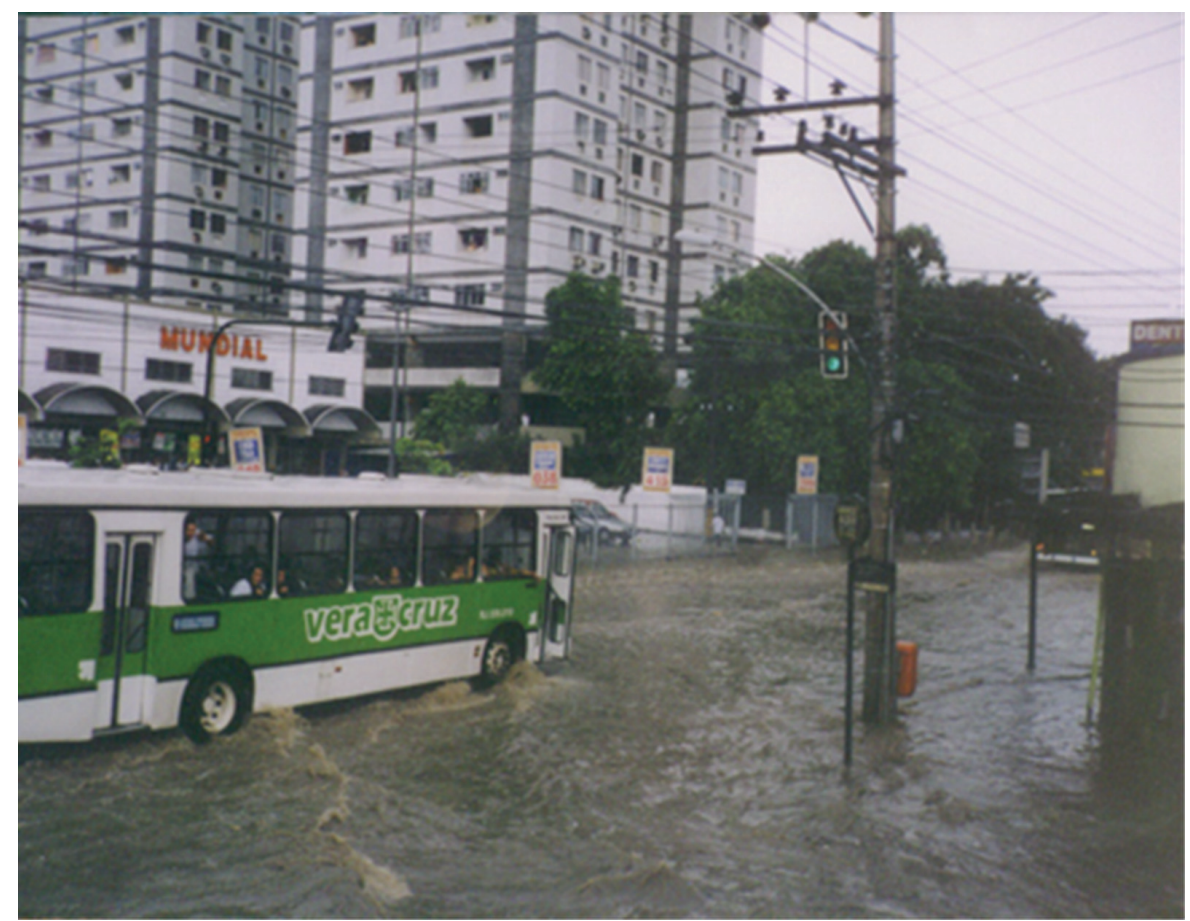

Figure 14: Flooding in the surroundings of Pinto Teles Park before the implementation of the flood control measure.

recover slope hill areas that are presently occupied irregularly. The figure shows a significant water level peak damping for the entire basin in a riverbank street near its outlet.

The entire study was presented in a workshop held jointly by the Federal University of Rio de Janeiro and Rio-Águas, the bureau office of Rio de Janeiro City Hall which was responsible for the management of the urban drainage system. As a consequence, various interactions took place and some results are visible. The City Hall implemented, as a test pilot, one of the interventions in the Orfanato River basin, transforming a wasteland into a public park with a detention pond. This new park, known as Pinto Teles, is shown in Figs 13-15. Reports for the effects of this intervention, after a rainfall period, show that surrounding areas that were usually inundated before the construction of this multifunctional landscape are now free from frequent flooding.

\section{CONCLUSIONS}

Developing countries suffer due to the growth of the so-called irregular city. The lack of the basic infrastructure necessary to accomplish urban growth in these cities is generally critical. One of the major concerns for these regions is to the problem of urban floods. Traditional engineering solutions alone cannot solve this problem and channel enlargement measures tend to transfer the problem to downstream reaches. Historical urban solutions have not always have looked at drainage problems. However, it has been found that the combination of hydraulic engineering, architecture and urbanism knowledge can provide an important improvement in the search for the construction of an equilibrate, harmonic and sustainable environment. Integrated actions over the urbanised watershed aimed at revitalization of the urban space and conservation of the natural environment may be 


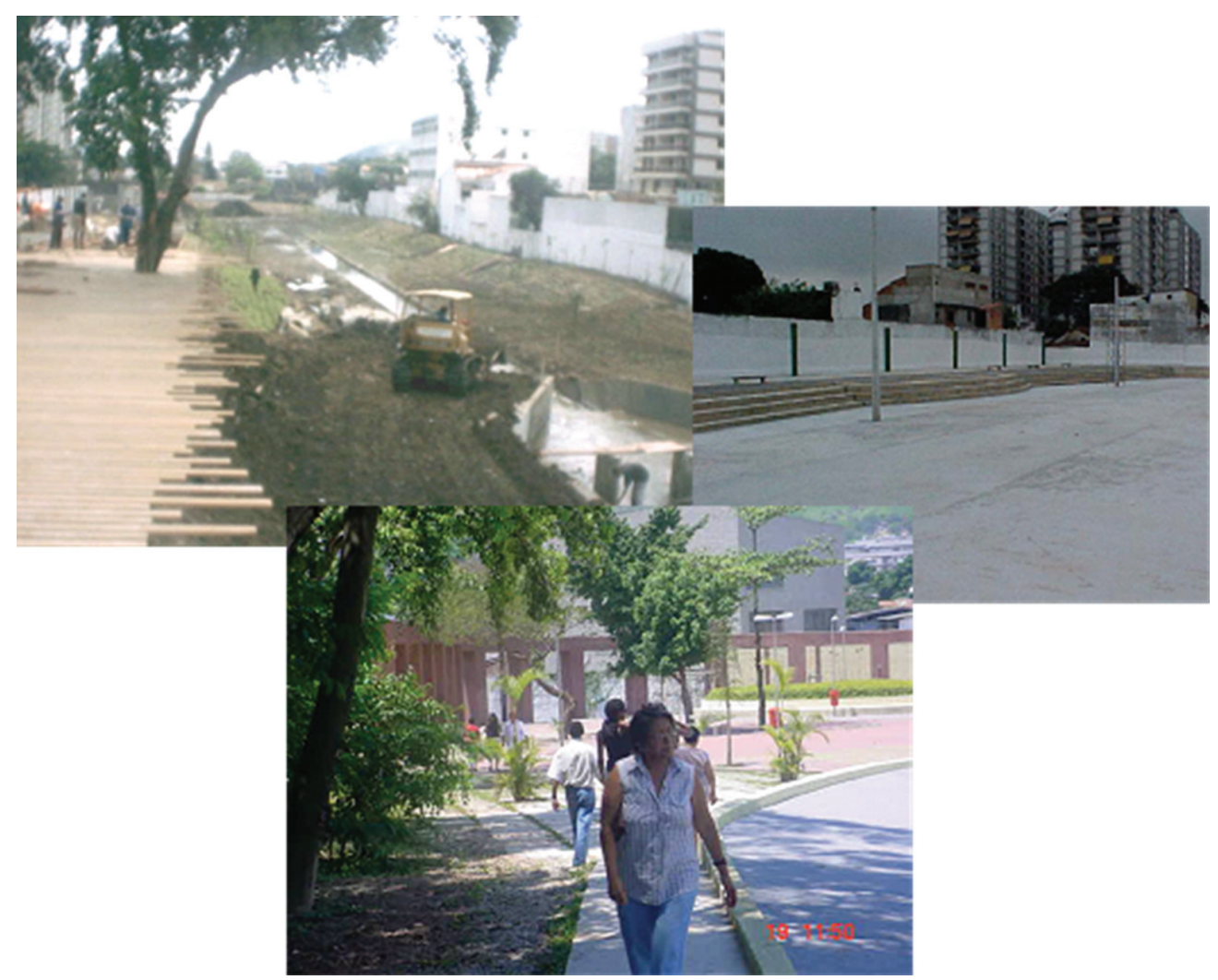

Figure 15: General view of the construction of Pinto Teles Park, a detailed view of the detention pond and a landscape view of the park after it was finished.

achieved by the incorporation of hydraulic functions into urban elements. This article, in particular, discusses a set of experiences from the city of Rio de Janeiro, with the Federal University reviewing a municipal programme for urban revitalisation. This study attempted to verify the effectiveness of flood control measures and to develop new concepts in integrated flood control design. These alternative proposals, as illustrated in the presented case study for Joana River, have shown the potential to generate positive results, by combining multidisciplinary efforts and optimising the application of the available resources, showing that city revitalisation and flood control can go hand in hand. Therefore, Rio de Janeiro City Hall and the Federal University of Rio de Janeiro are beginning to work together in a cooperative partnership to evolve a technique that will combine practical engineering, architecture, mathematical modelling and hydraulic research to produce better solutions for the urban flood problem.

\section{REFERENCES}

[1] Benevolo, L., La Città nella Storia d'Europa, Gius, Laterza \& Figli: Roma/Bari, 1993.

[2] Andoh, R.Y.G. \& Declerck, C., Source control and distributed storage - a cost effective approach to urban drainage for the new millennium? Proceedings of the 8th International Conference on Urban Storm Drainage, Sydney, Australia, 30 August-3 September, pp. 1997-2005, 1999. 
[3] AMEC Earth and Environmental Center for Watershed Protection, Georgia Stormwater Management Manual, Vol. 2, Technical Handbook, Atlanta, 2001.

[4] Coffman, L.S., Cheng, M., Weinstein, N. \& Clar, M., Low-impact development hydrologic analysis and design. Water Resources and the Urban Environment - Proceedings of the 25th Annual Conference on Water Resources Planning and Management, Chicago-Illinois, ed. E.D. Loucks, American Society of Civil Engineering: New York, pp. 1-8, 1998.

[5] Beatley, T., Green Urbanism - Learning from European Cities, Island Press: Washington, DC, 2000.

[6] Schilling, W., Cisterns against storms. Urban Systems Drainage, eds R.E. Featherstone \& A. James, Computational Mechanics Centre: London, pp. 4.49-4.60, 1982.

[7] O’Loughlin, G., Beecham, S., Lees, S., Rose, L. \& Nicholas, D., On-site stormwater detention systems in Sydney. International Conference on Innovative Technologies in Urban Storm Drainage, 2, Lyon. NOVATECH'95. Graie: Lyon, pp. 549-556, 1995.

[8] Hall, K.B. \& Porterfield, G.A., Community by Design, McGraw Hill: USA, 2001.

[9] Miguez, M.G., Flow Cell Mathematical Model for Urban Basins, DSc Thesis, COPPE/UFRJ, Rio de Janeiro, Brazil, 2001 (in Portuguese).

[10] Mascarenhas, F.C.B. \& Miguez, M.G., Urban flood control through a mathematical cell model. Water International, 27(2), pp. 208-218, 2002.

[11] Mascarenhas, F.C.B., Toda, K., Miguez, M.G. \& Inoue, K., Flood Risk Simulation, WIT Press: Southampton and Boston, 2005.

[12] Zanobetti, D., Lorgeré, H., Preissman, A. \& Cunge, J.A., Mekong Delta mathematical program construction. Journal of the Waterways and Harbours Division, 96(WW2), pp. 181-199, 1970. 